Improvement in the teaching of subjects is in direct proportion to the improvement of the teacher.

There followed a presentation of the Social Implication for Improving Instruction by Dr. Edgar G. Johnston.

\title{
SOCIAL IMPLICATIONS FOR INSTRUCTION
}

\section{DR. EDGAR G. JOHNSTON \\ Principal University High School, Ann Arbor, Michigan}

Social implications cannot be considered in a vacuum. They have significance only as they are related to a particular society at a particular period. Any meaningful discussion of the topic assigned to me must then take its start from a consideration of the kind of society America provides to-day and is likely to provide in the future. At the risk of indulging in platitude I wish to stress this point-that we are not preparing young people to live in Fascist Italy or Nazi Germany or Communist Russia, or in the United States in which we grew up. We are not even preparing them to live in a United States which will remain exactly what it is to-day. To equip young people adequately for the world of to-day and of to-morrow is the task which the school shares with other agencies, but for which it must undertake certain peculiar responsibilities.

Two characteristics of that contemporary society are especially significant for education. One is the dominating fact of developing technology and social change, constantly increasing in momentum and in the magnitude of the problems presented.

That these problems transcend local or sectional efforts for their solution is illustrated by a half dozen headlines gleaned from the front page of this morning's paper- "Five States Hit by Dust Storms," "Broad Farm Tenant Program Suggested," "House Group Considers Supreme Court Plan," "Program for Flood Control Proposed," "Negotiators Seek Agreement on Sit-Down Strike." Here are problems which, starting locally, affect the citizens of every state. Only' nationwide planning is adequate for their solution.

I am sure that it is not necessary to elaborate this point which has been voluminously developed in the publications of 
recent years. The important fact to point out here is that however much we may have talked about a changing society, we have done amazingly little about it in our schools. In the vernacular of the high-school youth with whom we are concerned: "It's a changing world, and so what?"

The other consideration which must govern any attempt to adapt instruction more adequately to social needs is the American concept of democracy. As conceived in the early days of our Republic and cherished by millions of Americans, democracy has meant something more than a kind of political machinery. It has meant essentially a way of life-one which places the common good above sectional or selfishly individual interests and which recognizes the inherent right of each citizen to a chance to develop his qualities to the full.

We may grant readily that the democratic ideal has been imperfectly achieved, that selfish interests have frequently influenced government to their ends. Throughout our history there has remained this ideal, against which practices could be measured and through appeals to which abuses could be corrected. With all its faults of omission and commission the fact remains that the commitment to a democratic form of government has made a tremendous diffference in the opportunities and responsibilities of the average citizen. The time has passed when a man could carry on his economic and social activities in relative isolation. Modern culture is essentially and irrevocably coöperative. The question is not whether we shall work collectively or not; it is, rather, "who shall determine the nature and direction of collective activity." The rising tide of dictatorship proposes one answer to this question. In Europe whole peoples have been regimented into unified and aggressive action under the direction of a dictator or a forceful minority group. We in America have chosen another path-that of free decision by popular will. We must recognize that our choice makes far greater demands on the intelligence and good will of the average man. The implications of this acceptance have been admirably discussed by Will French on pages 26 and 27 of the second report of the committee on Orientation.*

*Bulletin 64, Department of Secondary-School Principals. 
It is against this background of social change and the democratic tradition that the responsibilities of the school and the implications for instruction must be considered. Many considerations suggest themselves. Four seem outstanding both for their urgency if schools are to contribute significantly to the problems of our day, and because they have been so largely neglected.

Education in the high school must be more realistic. Pupils must be led to know at first hand the dynamic civilization of which they are a part. Important at anytime. if schools are not to be mere repositories of book-learning, this becomes imperative during periods of rapid change. This means that the classroom must be in continuous and vital contact with the realities of contemporary life. You will remember that Henry Adams at the close of his period of formal education found himself better equipped for life in the Rome of Julius Caesar than in the United States of Theodore Roosevelt. Only last December an "ex-teacher" writing in the Forum has this to say: "Is there one person in 100,000 who cares whether utor takes the ablative or the ablative takes utor? Do you actually know one person who uses cube root or quadratic equations in his daily business, or a radio listener who cares two whoops what a radio wave or vacuum tube is, or a housewife who is solicitous as to whether Alexander conquered Darius or Darius conquered Alexander? The answer is no, but we have assumed that it is yes. The people into whom we have tried to ram all this knowledge have no use for it and, therefore, no interest in it. This situation obtains as regards about 99 per cent of the curriculum." We are still a long way from streamlined education.

Many of the most vital instructional materials are not to be found between the covers of any textbook. Pupils have studied maps of Ancient Greece or of the Napoleonic Wars who have never mapped their own communities as a means of understanding civic problems. They have studied principles of physics and chemical formulae and never visited a modern industrial plant to see those principles in operation. They have studied facts of history and government, but have had no first hand contact with the actual operation of government in the tax collector's office, the traffic court, the school board meeting, or the state legislature. It must be emphasized that 
"excursions" in the educational sense don't mean pleasure trips. As used by some of the more progressive schools they are carefully planned features of the curriculum with pupils seeking at their sources the data necessary to solve problems which are real to the pupils. The illustration of a sociology class participating in the work of a social center which $\mathbf{M}$. P. Gaffney described in his excellent discussion of Issue III presents a splendid example of the functional realism for which I am pleading.

Realism also means bringing the community into the school in the use of those environmental agencies which have educational significance. The motion picture, the radio, and the daily press are important educational instruments which have been largely overlooked by formal education. They exert a powerful effect on educational outcomes, whether we do anything about it or not. There is here a challenge to the school to use the resources of these powerful, new instruments where they are constructive, to participate in their development as cultural agencies, and to develop in pupils a sense of discrimination toward the offerings of radio, press, and screen.

Young people need to receive increasing opportunities to participate in planning, in making decisions and evaluating the results of their effort. This demands a shift in the teacher's role. He becomes a partner in a coöperative enterprise rather than a dictator who assigns the exercises and knows all the answers. There is not time to develop in detail the changes which would result from acceptance of this obligation, but it is safe to say that it would represent nothing short of a revolution in most high schools. In many schools extra-curriculum activities have served a vital need in giving an outlet for pupil initiative and responsibility, and in providing an opportunity for pupils to learn tolerance and coöperation through the give and take of community life. The social demands which we are considering, however, require something much more far-reaching than this. In terms of growing maturity the pupil should be an active partner in all activities of the school. His participation should permeate the schoolroom and the laboratory as well as the playground. It should not stop there, if education is to be vitally linked with community life. His experiences in school should be made vital through 
application to real community problems. That encouraging beginning has been made through the activities of youth organizations (including the school) is evident in the recent volume, "Youth Serves the Community," by Paul Hanna. What more effective education can there be than active participation in service to the community?

The high school should help pupils develop the ability to sift fact from propaganda and to make decisions in the light of evidence. Modern invention has placed tremendous power in the hands of those who control the instruments of public opinion. We cannot turn the radio dial or pick up a newspaper without exposing ourselves to the special pleading of an interested individual or group. This presents a serious problem in a democracy.

The path of censorship is fraught with dangers as great as those it seeks to control. The only solution consistent with democratic theory is that based on providing the average citizen with the means of intelligent choice. The high school has an important role to play. Pupils should be led to be intelligently critical of statements presented for their approval. How valid are the claims for an advertised product? What are the arguments presented by spokesmen of each side in a labor dispute? What interests does a given newspaper, organization, or broadcaster represent? The school must be free to consider similar questions in the light of public interest alone. It has an obligation to prepare its pupils to protect themselves from misleading advertising and from the propaganda of pressure groups.

Instruction must help to develop a sense of social responsibility and a loyalty to the democratic ideal. It is here that education conceived as acquisition of facts breaks down. In the field of social relationship, we are interested not only in what an individual knows but in what he does and in his attitude toward his partners in the social enterprise. No longer is it a sufficient qualification of the good citizen to "mind his own business." His business is inevitably linked with yours and mine. The field of rugged individualism is narrowed with each new invention and each advance in social thinking. In a simpler era the young blood might come home from a convivial evening in high spirits with the lines wrapped around the whip 
and no one much the worse for his escapade. Turn him loose on a modern highway in a high powered car and he becomes a social menace. We may apply this analogy to every phase of our complicated social, economic, and political life. Limitation of freedom is the price we pay for modern civilization. In the words of C. A. Dykstra, the efficient and public spirited city manager of Cincinnati, "We must ask our schools to produce adults with self control, self discipline, and the ability to put themselves in the other fellow's place."

How develop this social sense? Certainly the answer is not to be found in moralizing-in the handing out of ready made precepts. The solution is not simple but unquestionably some schools are making marked progress in developing pupils who are socially sensitive and intelligently responsible. The school will make its chief contribution as it provides situations in which pupils are faced with problems involving social consequences and where the issue is put squarely up to them. The pupils imagination-and the teachers-must be quickened to think through solutions in terms of consequences to the individual and to the group. The school environment is rich in such inherent situations. The skillful teacher will be alert to see and use them.

The European dictatorships have captured the imagination of youth with high devotion and loyalty to a leader, a cause, an ideal. All the glamor of pageantry and the psychology of mass action have been used to hypnotize the populace into unswerving loyalty to the national ideal. We distrust the aims and the methods of the dictators but we can not afford to be less intelligent than they. It is our task as teachers to capture the loyalty and idealism of American youth for the American ideal-to build in them a sense of dignity, high adventure and stirring drama in the struggle for democracy. Such a concept presents a tremendous challenge to the school but we can accept no less if instruction is to play its part in preserving the values we cherish for the America of today and tomorrow. 